Ramon, X., \& Tulloch, C. D. (2019). Life Beyond Clickbait Journalism: A Transnational Study

of the Independent Football Magazine Market. Communication \& Sport. Online First.

https://doi.org/10.1177/2167479519878674

\title{
Life beyond Clickbait Journalism: A Transnational Study of the Independent \\ Football Magazine Market
}

\begin{abstract}
In a cluttered and increasingly complex environment characterized by the multiplication of platforms, a constellation of quality football print magazines has emerged as an alternative destination in sports journalism. To trace the expansion of the independent football magazine market, in-depth interviews were conducted with the editors of eight prestigious projects from seven countries: Howler (United States), Panenka and Libero (Spain), Mundial (United Kingdom), So Foot (France), 11 Freunde (Germany), Offside (Sweden), and Ballesterer (Austria). Independent football magazines position themselves as part of a journalistic counteroffensive to the metric-driven, routinized, and complacent approach that currently shapes mainstream sports media output. In contrast to the primary orientation of sports journalism towards economic capital, their editorial philosophy is built on three core axes aimed at developing cultural capital: (1) a diverse and multifaceted football agenda that embraces unheard voices and far-reaching issues of a sociocultural, geopolitical and economic nature; (2) the importance of dedicating time and resources to create a visually distinctive output; and (3) a deliberate emphasis on nostalgia and resistance to the seemingly endless commodification of
\end{abstract}


football. As part of their creative approach, gathering and nourishing a community of readers has been fundamental to the growth and sustainability of those projects.

Keywords: football independent magazines, sports journalism, diversity, nostalgia, design 


\section{Life beyond Clickbait Journalism: A Transnational Study of the Independent Football Magazine Market}

In the current cluttered, fluid and increasingly complex media environment, sports content is accessible through an expanding range of digital platforms, mobile devices, telecommunications operators, and service providers. As Hutchins (2014, p. 509) highlights, the "media sports content economy is now 'on the move"”. New technologies have created 'digital plenitude', contrasting with the relative undersupply in terms of platforms and quality of output that prevailed in the analogue age (Hutchins \& Rowe, 2009). While it is true that television still occupies a central space within the broader sports media landscape, audiences can choose from an increasingly diverse line-up of platforms to access sports content (Boyle, 2015; Grimmer, 2017; Hutchins, Li, \& Rowe, 2019; Hutchins \& Sanderson, 2017; Ramon \& Haynes, 2019).

This seemingly endless digital expansion (Carlson \& Lewis, 2019), however, has come with a cost to print media. In these times of structural change, legacy companies have suffered from the collapse of the traditional advertising-funding model combined with dwindling circulation numbers (Daum \& Scherer, 2018). Many newsrooms across the board have closed their operations or been downsized. In this unstable context, those organizations that stay alive are confronted with constrained resources.

In turn, media practitioners have become increasingly bound to the escalating pressures derived from the " $24 / 7$ production cycles, high speed information flow and the impact of social media" (Tulloch \& Ramon, 2017, p. 652). Although "for more than a century, the pace of journalism has been fuelled by the culture of the scoop and an ethos of competition" (Rauch, 2018, p. 35), speed has now become an almost sacrosanct component of the 'ASAP journalism' (Drok \& Hermans, 2016; Usher, 2014) news culture. Journalism has also been unequivocally 
affected by the fixation on metrics, the growing inclination towards predictable content, the reliance on public relations material, and the expansion of practices linked to news commodification and tabloidization, such as click-baiting (Conboy, 2014; Ferruci, 2018).

From the field theory perspective, sports journalism has been an area that has been primarily inclined towards economic capital rather than towards journalistic/cultural capital (Bourdieu, 1998; English, 2016). In the perpetual chase of economic capital, sports journalism has become "the world's best advertising agency" (Schultz-Jørgensen, 2005, p. 4), promoting athlete celebrities, topflight teams, and other agents within the sports-media complex. The interplay between news entities and the sports industry has raised many questions about the extent to which sports journalists lack the ability to act in a detached and responsible manner (Oates \& Pauly, 2007; Ramon, Billings, \& Rojas-Torrijos, 2019; Rowe, 2007).

To avoid jeopardizing their access in an increasingly controlled environment, critical issues have been sealed off in favour of a complacent approach based on 'boosterism', fascination, spectacle, and rumour (Boyle, 2017; McEnnis, 2018; Rowe, 2017). Routinely, most coverage is focussed on match-related elements, failing to illuminate the relevant economic, political, and social issues to which sports are inextricably connected. The information overload on male professional leagues and international mega-events frequently overlooks lower leagues, youth competitions, and women's games. The range of output, therefore, is characterized by repetition and uniformity (English, 2014) and by an overwhelming lack of diversity.

The alignment of sports journalism with the economic pole currently seems to be heightened, given the contemporary dynamics and challenges that affect the broader journalistic landscape (Serazio, 2019). The progressive shift towards provocative, entertaining and clickbait- 
oriented content seems to define how a large amount of sports news is currently being manufactured and packaged.

\section{The Emergence of the Quality Sports Magazine Market}

Surprisingly, in this environment characterized by diminishing resources, intensifying competition, and a rapid multiplication of media portals, there has been "a resurgence in the production of one of the oldest forms of media, the small-scale independently owned printed magazine" (Le Masurier, 2012, p. 383). Independent magazines can be defined as publications that are "producer-owned and made, occupying a zone of small-scale creative commercial publishing between DIY zines and mainstream niche consumer magazines" (Le Masurier, 2012, p. 384). They are built on small teams that are responsible for content creation, design, marketing and retail under an editorial philosophy that give those publications a particular idiosyncrasy (Johnson \& Prijatel, 2007).

As Das (2016, p. 1) highlights, "the story of magazine publishing is one of a medium, a product, and a business model that adapts and adopts". Over the last few years, technological developments have reduced production barriers, facilitating small-scale publishing. This shift has enabled a vast range of independent print magazines to flourish, giving space to what has been flagged as a modern publishing revolution (Davidson, 2019; Thorpe, 2018). In their search for a position in a crowded marketplace, independent outlets have been driven by creative work, that is, the relentless pursuit of useful and distinctive approaches concerning production modes, content, and commercial solutions (Malmelin \& Nivari-lindström, 2017; Runco \& Jaeger, 2012). Creativity also entails finding new ways to bond with readers and obtain their financial support through practices such as crowdfunding (Aitamurto, 2015). 
The unexpected appearance and consolidation of niche print publications such as Delayed Gratification and Another Escape (United Kingdom), Offscreen (Australia), Laine (Finland), Lagom (Sweden) and Jot Down (Spain) have been followed by the advent of quality sports magazines such as Volata, Conquista, Roleur, Peloton and Soigneur (cycling), Revista H and Rugby Journal (rugby), Racquet (tennis) and Like The Wind (running). Nevertheless, the centrality of football in the sports-media complex has made quality and highly specialized football print magazines blossom and occupy a distinctive role within their home markets. While sports magazines have always performed an important role within the wider media landscape, these elite football print magazines represent the latest step "to create a niche genre aimed at a passionate audience" (Pratt, 2013).

Progress has not always been smooth. For many publications, beginnings were modest, and not all the new entrants into the marketplace have been able to survive in the midst of the financial crisis that tremendously affects the media sector. Independent magazines such as The Green Soccer Journal (United Kingdom) and XI Quarterly (United States) struggled and had to close down operations after publishing a few issues, which illustrates the fragile and volatile nature of the contemporary environment, in which concerns about sustainability are all the greater. However, a plethora of titles still stand and have been consolidated as part of a 'golden age' for football magazines (Alderson, 2016).

As exponents of slow journalism (Ananny, 2016; Le Masurier, 2016), these publications have emerged as a backlash to the prevailing trend towards instantaneousness and superficial accounts of news events. By subverting the fixation on immediacy to seek a 'proper time', these publications have shifted away from the prevailing assumptions connected to the digital environment (Ball, 2016; Neveu, 2016; Zelizer, 2018). They have reclaimed the need to invest in 
a "high standard of writing and publication, accuracy, reflection, narrative, context, deep research, source checking and a rejection of interpretative clichés" and "the preservation of prestige through an obsession with quality and the power of narrative" (Tulloch \& Ramon, 2017, p. 653).

In contrast to large-scale media forms, characterized by conveying a fairly restricted, predictable and routinized agenda, these niche magazines aim to be meaningful creations that provide a greater understanding of football in its myriad manifestations. They circumvent the overabundance of insubstantial content and counteract the "boosterism of athletes, teams, organizations and the sports industry" (English, 2017, p. 532) and the "opinion-oriented, 'hot take' journalism formats" (Serazio, 2019, p. 4) that pervade the mainstream media coverage. These magazines properly explore the social, political, cultural, and economic ramifications of sports, seeking to address relevant and razor-edged questions rather than dealing with unchallenging and commonplace topics (Boyle, 2017). In terms of diversity, they pursue giving exposure to those significantly underrepresented in dominant outlets, including sportswomen (Franks \& O’Neill, 2016; Sherwood, Osborne, Nicholson, \& Sherry, 2017).

These magazines can be considered artefacts to be enjoyed as functional and aesthetic products (Ytre-Arne, 2011). Le Masurier (2012, p. 394) argues that the "magazine as a printed object can offer much more than digital screens: the quality and tactility of the paper, format (size, shape, binding), the integration of words, images and space as an expression of graphic design specific to print, and the life and function of the magazine as a material object".

To clearly define our object of study, it is necessary to draw the parallels and differences between the independent quality magazines and football fanzines, whose origins can be traced back to the mid-1970s. Influenced by punk culture, the fanzine phenomenon saw a publishing 
explosion in the late 1980s and early 1990s (Brewster, 1993; Haynes, 1995; Redhead, 2002) before lending space to online platforms such as fan websites or e-zines, and later, social media (Millward, 2008; Millward, 2017). In production terms, fanzines were produced by 'amateurs' with very low resources, being printed on small presses or photocopiers and with a nonprofit mindset (Boyle \& Haynes, 2004). This homemade approach contrasts with the high-quality production of today's independent magazines, which are aimed at obtaining commercial gains (Le Masurier, 2012). That being said, as will be noted, some independent magazines started as fanzines before developing their current business model. However, the reduced number of people - between three and five - participating in the writing and production of fanzines (Jary, Horne, \& Bucke, 1991) resembles the core staff that currently make most independent football magazines possible. Editorially, fanzines such as When Saturday Comes and Off the Ball opposed the increasing commodification of sports and sought to "compensate for the concentration of media interest largely on the most successful, big city teams" (Jary et al., 1991, p. 585). As will be argued later, these 'resistance' values are fully embraced by contemporary independent football magazines.

Despite the fact that the independent magazine market and the expanding range of publications within the slow journalism movement have been explored through various case studies and comparative research (Barranquero-Carretero \& Jaurrieta-Bariain, 2016; Dowling, 2016; Drok \& Hermans, 2016), the examination of quality football magazines has been largely neglected in the scholarly literature. Therefore, it is of utmost importance to understand the particularities of quality independent football magazines, scrutinize the strategic proposals offered by these projects and provide insight into their creative business models. This 
transnational analysis endeavours to bridge this gap in the field and establish the DNA of the independent football magazine market.

\section{Method}

The objective of this research has been to examine the expansion of the independent football magazine market and explain how these publications create cultural capital. Two research questions have guided the investigation:

- RQ1. What are the strategic proposals offered by independent quality football magazines concerning content and design?

- RQ2. Which are the business models of these publications and how do they remain sustainable in the current scenario?

To answer these questions, this transnational research analyses eight prestigious projects from seven countries: Howler (United States of America), Panenka and Líbero (Spain), Mundial (United Kingdom), So Foot (France), 11 Freunde (Germany), Offside (Sweden) and Ballesterer (Austria) (Table 1). A cross-cultural examination, encompassing representative outlets from different regions in Europe and beyond, was deemed indispensable to unravel the characteristics that form the DNA of quality football publications. Previous research in the field of sports communication (Horky, Clavio, \& Grimmer, 2018) has demonstrated the value of conducting an international comparative analysis.

Five of these magazines (11 Freunde, Offside, Ballesterer, So Foot, and Panenka) were chosen because they participated in a pioneer meeting organized by 11 Freunde in Berlin in 2013 to discuss the emerging phenomenon of independent football quality magazines and to establish an international network of collaboration (11 Freunde, 2013). Those trailblazing publications, 
now consolidated entities within their home countries, paved the ground for the appearance of subsequent magazines. In a time of audience fragmentation, those outlets attract a relatively small - but growing - readership that wants to go beyond the agenda displayed by general information outlets and by sports dailies such as Marca, As, Mundo Deportivo, Sport and L'Équipe; mainstream magazines such as FourFourTwo and WorldSoccer (United Kingdom), France Football (France), Kicker and Sports Bild (Germany); and club-owned publications such as 51 Das FC Bayern Magazin, PSG Le Mag, Celtic View, and Inside United, to list a few.

To broaden the range of outlets examined in the study, three quarterlies were incorporated into the sample. Mundial was launched in 2014 as a one-off for the Brazil World Cup. Departing from the growing roster of UK-based independent magazines focussed specifically on gear and fashion (for instance, Season and SoccerBible), Mundial has consolidated its broad-ranging view on football, printing 18 issues to date. Libero appeared shortly after Panenka and has now reached its 29 th issue. Both publications jointly stand out as the most important quality football magazines in Spain, a territory in which the longstanding weekly Don Balón disappeared from the newsstands in 2011. Howler became a pioneer in the USA and was later followed by other titles such as Eight by Eight. In a context dominated by established multisport outlets such as Sports Illustrated and ESPN The Magazine - and where Soccer America only remains in its digital form - Howler is now the longest-running quality independent football magazine in the country, with 17 issues published.

[Table 1 near here]

The qualitative method was chosen to conduct this study, as it offers a great deal of flexibility in the research design and in the collection and analysis of data (Brennen, 2013). Eight 
in-depth interviews were carried out with the editors of these publications: Dennie Wendt (Howler), Aitor Lagunas (Panenka), Diego Barcala (Libero), Dan Sandison (Mundial), Javier Prieto-Santos (So Foot), Tim Jürgens (11 Freunde), Anders Bengtsson (Offside), and Jakob Rosenberg (Ballesterer). Interviews, one of the most used techniques in social qualitative research (Kvale \& Brinkmann, 2009), have proved particularly useful to scrutinize sports media organizations across the board (Billings, 2008; Ramon et al., 2019; Serazio, 2019). This technique has definite advantages, these being the breadth and depth of nuances and details that are provided by first-hand descriptions and the possibility of getting closer to a part of the object of study that cannot be approached through content analysis (Rubin \& Rubin, 1995).

Interview scripts pivoted around the following core areas: the origins of the publications; their structure and staff; their particular values and the newsroom cultures in which they operate; the features that distinguish their editorial philosophy in terms of content and aesthetics; their creation processes and working routines; and the underlying aspects of the creative process. Conversations were also helpful to understand their business models, how they engage with their readership, and the challenges to remaining sustainable in this time of commercial constraints. Data about their average print run per issue and their current number of subscribers were also requested from the editors.

All the conversations, ranging between 40 and 90 minutes in length, were conducted between October and November 2018 either by Skype or on a face-to-face-basis. These interviews were audio recorded for subsequent transcription and detailed comparative analysis. Prior to conducting the interviews and to properly design the conversational guides (Kvale \& Brinkmann, 2009, p. 97), we collected information offered by these organizations on their websites and print copies from all the magazines from 2017 and 2018 (5 issues per magazine, 40 
in total). Accessing print copies allowed us to get acquainted with the nature of the products and select relevant examples of news content and design that were later discussed with each of the decision-makers.

\section{Results}

The 50-plus pages of interview transcript with the editors of the international magazines presented the authors with a great deal of material for analysis. Four major issues or themes have emerged from the conversations, serving as a transnational DNA of the quality football magazine market and the creative business models followed by these projects.

\section{"Reframing the Game" through a Diverse Agenda}

The first subject to come up across-the-board was the need to offer an alternative - and more diverse - content agenda. In contrast to clickbait and disposable content, these magazines pursue a broader editorial approach by exposing unique perspectives on football, offering great opportunities to widen the agenda and transcend the uniformity and similarity that can be so often found in sports stories (English, 2014). These publications shy away from a model based on the strict following of current events, which tends to be impregnated by many of the deficiencies and shortcomings (Horky \& Stelzner, 2013) that have characterized sports journalism "as a form of 'soft' journalistic practice, without the rigour and credibility of other forms of 'hard' journalism”' (Boyle, 2017, p. 497). Conversely, these magazines pursue promoting their passion for football through different angles, original content and in-depth work.

Bengtsson (Offside) spoke of two driving factors behind the content of his magazine: a disenchantment with routine football journalism - "how many stories can one write about Zlatan [Ibrahimović]?” - and a constant search for untold stories, whether they revolve around 
undiscovered teenagers, the world of the football agent or the stories underlying city rivalries.

Barcala at Spanish magazine Libero also spoke of how his staff had to change their mindset, given that they all came from "a school of generalist sports journalism", while Prieto Santos at So Foot accuses big hitters such as L'Équipe of "omitting the sociocultural and geopolitical nuances of football". Bengtsson agrees with this point, adding that "football explains so much about sociocultural life in cities and countries" and offering one poignant example of how this editorial philosophy was put into practice:

We have written a lot about refugees (...) in 2015 many Syrian refugees came to smaller villages in Sweden where their football clubs are dying due to a shortage of players. But now we have a lot of underage immigrants from Afghanistan who come to these villages and are saving these clubs and making the villages come alive again.

Rosenberg at Ballesterer was pragmatic about the need to diversify the content menu; he told us that for him, “a broad agenda is essential because it's our unique selling proposition”, while both British and American magazines understand an all-inclusive approach to be central to their projects. In this sense, Sandison at Mundial declared, "we want to remind people why they love football. That could be anything from an iconic kit, a football boot, playing FIFA with their friends (...) the Women's World Cup to nonleague football. Football is a powerful, diverse sport and we want to show that."

Wendt at Howler spoke of how a broader agenda allows his magazine to enter into a much wider narrative about identity and motivation issues tied to the game:

We're still discovering what it means to be an American within soccer. In an immigrant country, there are complications within that as well. So I think Howler and the other great soccer magazines have an opportunity to probe within those issues. (...) I recently heard about the only American woman playing in the South Korea soccer league. By the time I talked to her, she was playing in the Champions League for a team in Lithuania. I thought, what a great illustration of someone just following football wherever she finds it. That's what an American woman has to do to stay connected to the game. If we can share those stories, they 
can be so much more valuable to the American soccer community than writing about Spurs or Chelsea.

The Spanish football magazine editors toed a similar line. In this regard, Lagunas at

Panenka sees football as a Trojan horse to talk of larger issues: "We have a very broad radar and a wide cartography of themes. In Spain, football and culture have never really gone together, but in the last ten years, this has improved, and, modestly, I think Panenka may have had a role to play (...) I love writing about politics, social issues, equality, [and] apartheid using football as the excuse". Prieto Santos, editor at French magazine So Foot, employed the same metaphor when declaring,

Football is an excuse for us to talk of other issues. Our slogan is football, culture and society. We talk about race issues, integration and homophobia. We were the first to put racism in football on the front cover. We are also the first to put a physically handicapped person on the front page when everyone said this wouldn't sell. Our modest aim is to make new inroads in this sense.

Therefore, these magazines demonstrate a great capacity to transcend borders to explore stories in many different contexts while offering in-depth reporting on the larger framework of football and expanding their coverage to embrace far-reaching issues of a cultural, social, political, economic, and technological nature connected to the sport.

This alternative agenda helps to define and reinforce these magazines' sense of uniqueness. Sandison at Mundial told us, "we still think we are a unique publication in terms of the aspects of the game we cover and how we cover them," while Jürgens at 11Freunde said his publication "takes a different approach to everything in the other German football magazines, like Kicker or SportsBild. This is our dogma for both our writing and our graphic layout." Lagunas said Panenka was born "because it was the magazine that many of us wanted to read and buy at the newsstands. So given that it wasn't there, we did it," while Prieto Santos at So Foot proudly announces, "While the others are interested in Messi and Cristiano, we're interested in the ugly guy who hasn't scored a goal all season but has a crazy life off the pitch. 
That's why we love the George Bests. We like the antiheroes". Thus, as a central trait of their DNA, these publications go to great lengths to give visibility to other faces and teams beyond well-known stars, placing the focus on inspiring stories of underdogs and forgotten players. They also showcase women's football and grassroots sports. This practice reveals the great power of these publications to amplify "otherwise unheard voices" (Belt \& South, 2016, p. 551), a proposition that contributes to nourishing readers' knowledge about sports.

\section{"No to Modern Football": The Heightened Importance of Nostalgia and Tradition}

Nostalgia, retrospective essentialism and a spirit of resistance are also present in the independent magazine DNA. Nostalgia, a concept connected to "the notion of collective, social or cultural memory" (Pickering \& Keightley, 2006, p. 922), can be understood as an earlier time that "brings joyful memories" (Bolin, 2015, p. 252). Many editors recognize their debt to sports journalism classics. Jürgens (11 Freunde) recognized that he was inspired by Nick Hornby’s 1990s hit novel Fever Pitch, which is itself a throwback to football in the 1970s, while Wendt (Howler) spoke openly of being influenced by "the old days of Sports Illustrated. I just love those great old sports writers".

Many of the editors interviewed interpreted this interest in storytelling as a reaction against fast food sports journalism characterized by clickbait and teaser techniques. This point was particularly true vis-à-vis the American and British magazines. Whilst declaring himself not to be "antisocial media", Wendt at Howler did advocate "deeper storytelling", given that "people are hungry for it", and expressed his wish that "in my hopes and dreams, Howler can become a kind of a camp fire where all those stories gather round and whether its print, online or film, it doesn't matter as long as we are creating stories and helping people get them out there...That's what we want to do - find those storytellers, share those stories, and build a culture". Sandison at 
Mundial agrees, stating, "we benefitted from people tired of the internet. Clickbait journalism was at its peak when we were founded; football had been reduced to rumours and statistics. People were ready for something more thoughtful. Like people going back to vinyl records, we provided an alternative".

A spirit of anticommercial resistance weaves its way in alongside the revindication of this nostalgia. Many of the examined publications employ the theme "no to modern football" to deliberately reflect on the need to regain authenticity against the seemingly endless commodification of the sport. In this regard, Jürgens told us that in his case,

we want to see ourselves as a magazine which shows how much commercialism is changing the game and we don't want that (...) 11Freunde has to take care that our magazine is not part of the football business because we started out as a magazine which wants to be the opposite to commercialization. We must never be part of the mainstream football business. This is very important for our survival. You are injected with the football virus when you are six or seven years old, and so your approach is always to look back on older times, how it was in the 70s or 80s. If you want to show how commercialization has changed football, you have to show people how football was back in the day. So nostalgia and tradition have an important impact.

Jürgens considered When Saturday Comes (WSC) - a publication that started out as a fanzine and that fully embraced the idea of anticommercial resistance - one of the main inspirations of 11 Freunde. This nod to WSC was also outlined by Rosenberg (Ballesterer) and Prieto Santos (So Foot).

The editors agree regarding the relevance of tradition. Sandison declared that at Mundial, "we love reminding people why they fell in love with the game... In this sense, modern football is just as important. There are kids on terraces and in front of televisions who are making these memories now." Others spoke of the deliberate nostalgic pitch they make to their readers. On this subject, Bengsson (Offside) could not be clearer: "Of our five big stories in every issue, we have one that is more like retro. We know that sports enthusiasts really like nostalgia... we can 
use history to say something about the past, the present and the future. You can't write about a club without looking back to history".

Barcala (Libero) said, "Nostalgia is one of our strong points; we think there is a huge space for vintage and retro themes", while Lagunas confessed that Panenka "has a retro background focussed above all on the 80 s and 90 s, which is the football we remember". In an interesting reflection, Wendt (Howler) takes the nostalgia debate one step further by advocating a revamped vision of the journalistic resort to the past by referring to this option in different terms:

Someone told me at an ad agency that, thanks to YouTube, there is no longer a difference between old and new, only a difference between cool and uncool (...) American basketball and American baseball do a great job of keeping history alive and telling stories that are just plain cool. So I want to get to that point where we don't treat it as nostalgia at all (...) The Rolling Stones aren't nostalgia. The Rolling Stones are cool.

By acknowledging the history of the game in its myriad forms - from players, clubs and stadiums to 'retro' jerseys, films and videogame systems - and promoting the recreation and reimagination of the past (Higson, 2014), these magazines have therefore become "cultural artefacts that facilitate nostalgia as a way of feeling and thinking” (Pickering \& Keightley, 2006, p. 930) about football. Through this constant recreation and re-imagination of sports history, these magazines "reinforce a sense of cultural continuity" (Conboy, 2007, p. 267) around football, relating the past to the present. By being 'carriers of nostalgia', these publications contribute to generate cultural value and create an emotional connection with the reader.

\section{Magazines "Fit for Aesthetes"}

Aesthetic values, refined presentation criteria and attention to design form part of the independent football magazine product. Far from being a side issue, how the publication looks and feels emerges as central to its identity. In this sense, Sandison (Mundial) said that his magazine "aims at people who want to unwrap something, hold it in their hands and keep it on 
their shelves. Everything we do, from the design to the content, feeds into this". Across the board, the physical interface with the product was flagged as relevant. The sampled products offer the reader first-rate print reproduction on very high-quality paper. Rosenberg (Ballesterer) said, "The feel of the magazine, the touch of the paper is still a very nice sensation. People want to have something in their hands". The editor of Panenka went even further when highlighting the physicality of the magazine, claiming that "what sets us apart is that we have banked on paper, on touch, on smell. Many readers speak of the smell of the print. Tablets cannot reproduce this. This collectionist thing, the fact that the magazine spines together make a small drawing... it is still an artisan product".

Along with the 'collectability' factor and the attraction of the physical interaction with the magazine, other editors spoke specifically of how financial resources had been assigned to strengthening the visual impact of their publications. Rosenberg explained that Ballesterer held a design-led relaunch five years ago because, according to the Swedish editor, "it's very important to look good graphics-wise. It's not just about text. Graphics and text must work together." Lagunas said that attractive visual features were introduced to make Panenka stand out: "when the magazine was founded, many readers were concerned about its look. I'm not a specialist in design, so one of the first things we did was to look for a layout specialist. Many people told us, 'it doesn't look like a football magazine; it looks like an architecture magazine or about tendencies'. This was deliberate on our part. I wanted it to be different in the way it looks, not just the content".

For his part, Wendt (Howler) confessed that his previous position at Nike had helped him to fully understand how design is crucial to attracting readers, declaring, "We must understand how compelling visual can be in terms of drawing people into reading... Soccer people are 
visual people... it's one more way to charm and engage people. There is great value in supporting illustrators and photographers. It's our contribution back to the creative community".

The editorial decision to dedicate time and resources to the looks of the magazines forms part of these products' attempts to weave themselves into the cultural habits and lifestyle of their readers and thus elevate themselves out of the heavily populated media marketplace to offer a product worthy of collecting and that may work itself onto the bookshelves of their readership or subscribers. The physical and artistic characteristics of these magazines are thus geared towards increasing the longevity of their shelf life. In contrast to the "extreme transience and ephemerality" (Barranquero-Carretero \& Jaurrieta-Bariain, 2016, p. 522) of clickbait sports journalism, these magazines are made "with a long collectible life in mind" (Le Masurier, 2012, p. 394).

\section{Building a Community of Readers to Achieve Sustainability}

Interviews with the editors reveal that, concerning the independent football magazine DNA chain, links can be made that connect the alternative editorial agenda and anticommercial strains previously mentioned here to this revindication of a physical, artisan and collectable product that resists the comparatively cold interface of its tablet-based digital competitors. That said, how does this pitch affect sales? If there is a certain counterculture feel to these magazines, how does this feel translate financially? What is the capacity for sustainability of such a niche product?

A common trait that emerges from the interviews with the magazines' editors is the level of improvisation behind the business model in their origins. Mundial was described by its editor as a "one-off passion project" that continued because "readers and brands asked us to create another issue and it sort of accidentally became a full-time thing”. Many others make mention of 
the humble fanzine origins of their publications in stark contrast to the slick design of today's magazines.

Rosenberg at Ballesterer spoke of the magazine's do-it-yourself beginnings in which three friends "did everything by themselves", including copying the magazine at the local photocopy store before going to the stadium to sell it. Spurred on by having sold 300 copies, they put together another one, and the magazine took off. Others had equally precarious starts. For example, So Foot began with capital of just 450 euro, the help of a printer and short-term financial backing for just three issues. Bengtsson said that "for the first three or four years, Offside was like an underground magazine with just 2,000 subscribers and exclusively part-time staff".

Some magazines made no business plans at all. Prieto Santos confessed, "We were very innocent. There was no marketing and no search for advertising, as we simply had no money. We wrote what we wanted when we wanted without worrying about our readers' tastes or the needs of our advertisers. That defined our style at So Foot." Others made significant mistakes in their financial planning. Barcala at Libero explained, "When we made the business plan, the idea was to fund the magazine through advertising and sales at kiosks. But our main source of revenue has been subscriptions, which make up $40 \%$ of our income". In general terms, subscriptions make up approximately $50 \%$ of all magazine revenue, while advertising is responsible for a further $35 \%-40 \%$, leaving newsstand and bookshop sales to make up the rest. Many editors have not forgotten these modest backgrounds and the involvement of fans and readers in getting their projects kickstarted. Many of these magazines have been indebted to their readership from the beginning and maintain a close relationship with them. This 'crowdfunding' mentality continues, as can be seen from Offside's decision to say no to 80,000 
euro a year from betting company advertisers. As editor Bergsson expressed, "Now the readers understand why they need to support us". 11Freunde also values its relationship with its subscribers and offers outlet for direct feedback and contact with editorial staff. As Jürgen explains, "Every year, we give an award to the best player and best coach of the year. Readers can come and take part in the event. Sometimes, we run a quiz, and the winners can have an evening with the 11 Freunde writers. Then we go home for a beer and discuss football culture".

Their active presence in multiple digital channels, including websites, newsletters, podcasts and social networks such as Twitter and Facebook, not only helps to enable the “distribution and marketing of printed magazines" (Le Masurier, 2012, p. 385) but also contributes to reinforcing the brand, enhancing the sense of belonging and gaining a wider potential audience. This feedback from readers has another function; it serves to audit the magazine and keep it true to its original philosophy, as Lagunas explained:

We had feedback right from the start. That's when I realized that this would work. People responded and wanted to participate. Our readers quickly made it theirs and complained when the front cover of issue 3 featured the city of Rosario and had Messi on the cover. They told us that Panenka should not go that way, so we quickly realized that our readers were militants and were closely following us as a magazine and as an idea.

Although their magazines have undoubtedly entered a phase of consolidation, many editors pointed out that resources are still relatively limited. Seven staff work fulltime at Mundial, and Libero has a basic staff of five, while Howler was described by its editor as "just a couple of independent guys trying to make it work". Many do not have a physical newsroom, and production problems constantly crop us, as each issue draws on between 15 and 20 contributing writers who, as freelancers, often work for multiple outlets, making planning a difficult task. Wendt (Howler) could not be more frank when he confessed, "The short answer is that we're still learning", while Prieto Santos admitted, "We have grown, but we are still 
amateurs in the way we manage things. We still think we don't need a business plan or marketing studies. People see So Foot as a start-up, although we certainly don't work like one".

Aside from subscription rates, advertising and street sales, some of these magazines draw additional income from associated marketing initiatives that reinforce the brand. Through online stores, they offer a range of subsidiary products to encourage readers to show their loyalty, such as monograph issues, books, branded football jerseys, hats, 'retro' bags, calendars, lithographs and even vinyl records. 11 Freunde makes available for sale many of the pictures that are published in the magazine and shirts featuring football culture quotes. As Jürgens stated, "It's called the $11 \mathrm{~F}$ picture world. We sell the merchandise with funny quotes or T-shirts because we are a trademark. I think good journalism is only possible when you are a responsible, fair and strong trademark". This tie-in merchandizing is an additional source of revenue and helps to consolidate a community of shared interests. In this sense, Lagunas commented that "merchandising has helped us to consolidate and deepen the idea that football culture is a community in which Panenka can play a role".

Collaborative plans to reduce costs have recently been floated. Bilateral projects have materialized. Offside and 11 Freunde occasionally work together, and So Foot joined 11 Freunde for a Franco-German issue in late 2018 for the centenary anniversary of the First World War, which included interviews with Karl-Heinz Rummenigge and Michel Platini. Multilateral contacts were also toyed with back in 2013, when the magazines joined forces to found an independent football magazine federation. However, there is no organized structured network, as all are victims of short-term production cycles. As Rosenberg (Ballesterer) pointed out, "While there are some loose contacts, people are too busy with their daily work". 


\section{Discussion and conclusion}

In this digital age characterized by the multiplication of screens and platforms (Carlson \& Lewis, 2019; Hutchins et al., 2019; Hutchins \& Sanderson, 2017; Lotz, 2018) and a hyper-accelerated news culture (Drok \& Hermans, 2016; Usher, 2014), a constellation of quality, independent football print magazines has emerged and consolidated as an alternative destination in sports journalism. Through a qualitative approach, this transnational study has examined eight publications in Europe and the United States of America. Building upon the spirit of longestablished football magazines such as When Saturday Comes and Sports Illustrated and incorporating the traits associated with the expanding slow journalism movement (Le Masurier, 2016), these independent magazines have gone far beyond to establish themselves as distinctive products that shift away from mainstream football coverage. The digital revolution has disrupted sports journalism in unforeseen ways. For many organizations across the board, technology has translated into dizzying cycles and a reckless quest for traffic. Nevertheless, other entities are leveraging technology to offer new products that rethink what should be the defining metric in journalism. For independent football magazines, quality in content and design is the bottom line.

As unexpected entrants in the contemporary media sports content economy, independent football magazines have positioned themselves as part of a journalistic counteroffensive to the metric-driven, routinized, and complacent approach that currently shapes many of the mainstream sports media outlets (Boyle, 2017; English, 2014; Horky \& Stelzner, 2013; McEnnis, 2018; Serazio, 2019). In contrast to the primary orientation of sports journalism towards economic capital (Bourdieu, 1998; English, 2016), the editorial philosophy and creative work of these projects are aimed at developing cultural capital. 
Interviews reveal that journalistic capital is pursued through a distinctive approach based on three core axes: (1) a diverse and multifaceted football agenda that embraces unheard voices, alternative angles and far-reaching issues of a sociocultural, geopolitical and economic nature; (2) the importance of dedicating time and resources to create a visually distinctive output; and (3) a deliberate emphasis on storytelling, nostalgia and the need to resist clickbait journalism and the seemingly endless commodification of the sport. The spirit of resistance against the commercialization of the game and media's concentration on topflight teams (Jary et al., 1991) clearly links contemporary independent quality magazines and the football fanzine phenomenon.

These three core axes contribute to counterbalance the widespread shortfalls that have long characterized sports journalism as "the toy department" or the "sandbox" of the newsroom (Rowe, 2007). In addition, these components have allowed independent magazines to stand out in the current cluttered marketplace, facilitating a deep connection with audiences who find value in their clickbait-detox proposition. As part of their creative approach (Malmelin \& Nivarilindström, 2017), gathering a community of readers has been fundamental to the growth and sustainability of these projects. The shift from do-it-yourself fanzine beginnings (Haynes, 1995) to full-fledged publications has been possible thanks to the involvement of readers and their continued support of the editorial philosophy of the magazines. Transcending the traditional funding model that mostly depended on advertising, a subscription-based approach combined with street sales has been complemented by marketing and commercial initiatives created to consolidate and expand those loyal communities.

Although these magazines have come a long way from their humble origins, the limited resources available and the uncertainty that pervades the current media landscape should encourage them to continue searching for new ways to broaden their readership. Potential 
opportunities include broadening diversity by giving more visibility to protagonists that currently remain on the periphery of the media-sports complex (for instance, disabled footballers), staying updated with innovative ways of engaging with the audience - online and offline - and pushing forward the transnational network between projects that share a common editorial philosophy.

Information from seven different countries helps to advance true understanding of this rising phenomenon. Insightful comments from the interviewees can jointly inform industry representatives as well as from scholars around the world. Editors and decision-makers from existing publications or new entrants into the market can benefit from the practices that have made these publications unique and appealing to a loyal fanbase. The analysis also reveals that incorporating "a suite of creative and innovative for-profit approaches" (Le Masurier, 2016, p. 409 ) is essential to diversify income and ensure the sustainability of such independent projects.

The present study serves as a useful benchmark for future research on quality sports magazines. Scholars must continue monitoring the football print magazine constellation to analyse the patterns of continuity and change in the editorial propositions and business models of the examined magazines and other specialized outlets such as Zwölf(Switzerland), Josimar (Norway), Undici (Italy), and Mundial JP and Shukyu (Japan). In addition, although football remains the "sine qua non of the media sports world" (Boyle \& Haynes, 2009, p. 205), further avenues must be explored. To widen the scope of the analysis presented here, further crosscomparative research must be carried out to examine other quality sports magazines beyond football. Following the approach of the present study, in-depth interviews with editors and journalists in other countries and regions would be valuable to obtain a richer insight into their strategic proposals and scrutinize how they are similar to or different from the DNA traits that emerged from the football magazine analysis. 
In addition, interviews and focus groups with readers will also be required to obtain a wider picture of the phenomenon. Some of the magazines' editors think of their audience as being "smart, educated, and open to reading about all aspects of the game" (Anderson, 2013). Beyond this general assertion, a much more nuanced understanding is needed about the readers' and subscribers' expectations, motivations and experiences with those print magazines in this age of 'digital plenitude'. 


\section{References}

11 Freunde (2013, November). Wer bin ich? 11 Freunde, 144, 27-33.

Aitamurto, T. (2015). The role of crowdfunding as a business model in journalism: A fivelayered model of value creation. In L. Bennet, B. Chin, \& B. Jones (Eds.), Crowdfunding the future (pp. 189-205). New York: Peter Lang.

Ananny, M. (2016). Networked news time. Digital Journalism, 4, 414-431.

Alderson, R. (2016). The fall and rise of the football magazine. Retrieved from: https://magculture.com/the-fall-and-rise-of-the-football-magazine/

Anderson, G. (2013). Howler magazine scores! Retrieved from https://www.printmag.com/featured/howler-magazine/

Ball, B. (2016). Multimedia, slow journalism as process, and the possibility of proper time. Digital Journalism, 4, 432-444.

Barranquero-Carretero, A., \& Jaurrieta-Bariain, G. (2016). Slow journalism in Spain: New magazine startups and the paradigmatic case of Jot Down. Journalism Practice, 10, 521538.

Belt, D., \& South, J. (2016). Slow journalism and the out of Eden Walk. Digital Journalism, 4, $547-562$.

Billings, A. C. (2008). Olympic media: Inside the biggest show on television. London, England: Routledge.

Bolin, G. (2015). Passion and nostalgia in generational media experiences. European Journal of Cultural Studies, 19, 250-264.

Bourdieu, P. (1998). On television and journalism. London: Pluto Press. 
Boyle, R. (2015). The written press and social media perspectives. In M. M. Parent \& J. L. Chappelet (Eds.), Routledge handbook of sports event management (pp. 355-370). London, England: Routledge.

Boyle, R. (2017). Sports journalism: Changing journalism practice and digital media. Digital Journalism, 5, 493-495.

Boyle, R., \& Haynes, R. (2004). Football in the New Media Age. London, England: Routledge. Boyle, R., \& Haynes, R. (2009). Power play. Sport, the media and popular culture. Edinburgh, Scotland: Edinburgh University Press.

Brewster, B. (1993). When Saturday Comes and other football fanzines. The Sports Historian, 13, 14-21.

Brennen, B. S. (2013). Qualitative research methods for media studies. New York, NY: Routledge.

Carlson, M., \& Lewis, S. C. (2019). Temporal reflexivity in journalism studies: Making sense of change in a more timely fashion. Journalism, 20, 642-650.

Conboy, M. (2007). A tale of two battles. Media History, 13, 257-271.

Conboy, M. (2014). Celebrity journalism - an oxymoron? Forms and functions of a genre. Journalism, 15, 171-185.

Das, S. (2016). Magazine publishing innovation: Two case studies on managing creativity. Publications, 4, 1-12.

Daum, E., \& Scherer, J. (2018). Changing work routines and labour practices of sports journalists in the digital era: A case study of postmedia. Media, Culture \& Society, 40, $551-566$. 
Davidson, J. (2019). The independent magazine revolution. Retrieved from: https://www.weheart.com/2019/02/26/independent-magazine-revolution-indie-publishing/

Dowling, D. (2016). The business of slow journalism: Deep storytelling's alternative economies. Digital Journalism, 4, 530-546.

Drok, N., \& Hermans, L. (2016). Is there a future for slow journalism? Journalism Practice, 10, $539-554$.

English, P. (2014). The same old stories: Exclusive news and uniformity of content in sports coverage. International Journal of Sport Communication, 7, 477-494.

English, P. (2016). Mapping the sports journalism field: Bourdieu and broadsheet newsrooms. Journalism, 17, 1001-1017.

English, P. (2017). Cheerleaders or critics? Australian and Indian sports journalists in the contemporary age. Digital Journalism, 5, 532-548.

Ferruci, P. (2018). It is in the numbers. How market orientation impacts journalists' use of news metrics. Journalism. Advance online publication. doi: 10.1177/1464884918807056

Franks, S., \& O’Neill, D. (2016). Women reporting sport: Still a man’s game? Journalism, 17, 474-492.

Grimmer, C. G. (2017). Pressure on printed press: How soccer clubs determine journalism in the German Bundesliga. Digital Journalism, 5, 607-635.

Haynes, R. (1995). The football imagination: Rise of football fanzine culture. London: Arena.

Higson, A. (2014). Nostalgia is not what it used to be: Heritage films, nostalgia websites and contemporary consumers. Consumption Markets \& Culture, 17, 120-142. 
Horky, T., Clavio, G., \& Grimmer, C. (2018). Broadcasting the world cup: A multinational comparative analysis broadcast quality in the 2014 world cup. Soccer \& Society. Advance online publication. doi:10.1080/14660970.2018.1448794

Horky, T., \& Stelzner, B. (2013). Sports reporting and journalistic principles. In P. Pedersen (Ed.) Routledge handbook of sport communication (pp. 118-127). Abingdon, England: Routledge.

Hutchins, B. (2014). Sport on the move: The unfolding impact of mobile communications on the media sport content economy. Journal of Sport and Social Issues, 38, 509-527.

Hutchins, B., Li, B., \& Rowe, D. (2019). Over-the-top sport: live streaming services, changing coverage rights markets and the growth of media sport portals. Media, Culture, $\&$ Society. Advance online publication. doi: 10.1177/0163443719857623

Hutchins, B., \& Rowe, D. (2009). From broadcast scarcity to digital plenitude: The changing dynamics of the media sport content economy. Television \& New Media, 10, 354-370.

Hutchins, B., \& Sanderson, J. (2017). The primacy of sports television: Olympic media, social networking services, and multi-screen viewing during the Rio 2016 games. Media International Australia, 164, 32-43.

Jary, D., Horne, J., \& Buckle, T. (1991). Football 'fanzines' and football culture: a case of successful 'cultural contestation'. The Sociological Review, 39, 581-597.

Johnson, S., \& Prijatel, P. (2007). The magazine from cover to cover. New York: Oxford University Press.

Kvale, S., \& Brinkmann, S. (2009). Interviews. Learning the craft of qualitative research interviewing. Thousand Oaks, CA: Sage. 
Le Masurier, M. (2012). Independent magazines and the rejuvenation of print. International Journal of Cultural Studies, 15, 383-398.

Le Masurier, M. (2016). Slow journalism: An introduction to a new research paradigm. Digital Journalism, 4, 405-413.

Lotz, A.D. (2018). We now disrupt this broadcast. How cable transformed television and the Internet revolutionized it all. Cambridge, MA: The MIT Press.

Malmelin, N., \& Nivari-Lindström, L. (2017). Rethinking creativity in journalism: Implicit theories of creativity in the Finnish magazine industry. Journalism, 18, 334-349.

McEnnis, S. (2018). Toy department within the toy department? Online sports journalists and professional legitimacy. Journalism. Advance online publication. doi: $10.1177 / 1464884918797613$

Millward, P. (2008). The rebirth of the football fanzine. Using e-zines as data source. Journal of Sport \& Social Issues, 32, 299-310.

Millward, P. (2017). Football and social media. Fanzines, fan scenes and supporter protest movements in elite English football. In J. Hughson, K. Moore, R. Spaaij, \& J. Maguire (Eds.), Routledge handbook of football studies (pp. 189-199). Abingdon, England: Routledge.

Neveu, E. (2016). On not going too fast with slow journalism. Journalism Practice, 10, 448-460.

Oates, T.P., \& Pauly, J. (2007). Sports journalism as moral and ethical discourse. Journal of Mass Media Ethics, 22, 332-347.

Pickering, M., \& Keightley, E. (2006). The modalities of nostalgia. Current Sociology, 54, 919941. 
Pratt, T. (2013). An imported sport, soccer gets new glossy magazines in the U.S. Retrieved from https://www.nytimes.com/2013/12/30/business/media/an-imported-sport-soccer-gets-itsown-glossy-magazines-in-the-us.html

Ramon, X., Billings, A. C., \& Rojas-Torrijos, J. L. (2019). Interviews with former ESPN ombudsmen/public editors Kelly McBride, Robert Lipsyte, and Jim Brady. International Journal of Sport Communication, 12, 28-35.

Ramon, X., \& Haynes, R. (2019). Sports coverage on BBC ALBA: Content, value, and position in the Scottish broadcasting landscape. Communication \& Sport, 7, 221-243.

Rauch, J. (2018). Slow media. Why "slow" is satisfying, sustainable, and smart. New York, NY: Oxford University Press.

Redhead, S. (2002). Post-fandom and the millennial blues: The transformation of soccer culture. London, England: Routledge.

Rowe, D. (2007). Sports journalism: Still the 'toy department' of the news media? Journalism, 8 , $385-405$.

Rowe, D. (2017). Sports journalism and the FIFA scandal: Personalization, co-optation, and investigation. Communication \& Sport, 5, 515-533.

Rubin, H. J., \& Rubin, I. S. (1995). Qualitative interviewing. The art of hearing data. Thousand Oaks, CA: Sage.

Runco, M.A., \& Jaeger, G.J. (2012). The standard definition of creativity. Creativity Research Journal, 24, 92-96.

Schultz-Jørgensen, S. (2005). The world's best advertising agency: the sports press. Retrieved from https://www.playthegame.org/upload/Sport_Press_Survey_English.pdf 
Serazio, M. (2019). The power of sports. Media and spectacle in American culture. New York, NY: New York University Press.

Sherwood, M., Osborne, A., Nicholson, M., \& Sherry, E. (2017). Newswork, news values, and audience considerations: Factors that facilitate media coverage of women's sports. Communication \& Sport, 5, 647-668.

Thorpe, V. (2018). Smart, cool ... and in print: how indy mags became all the rage. https://www.theguardian.com/media/2018/jul/22/independent-magazines-buck-trend-forprint-decine

Tulloch, C., \& Ramon, X. (2017). Take five: How sports illustrated and L’Équipe redefine the long-form sports journalism genre. Digital Journalism, 5, 652-672.

Usher, N. (2014). Making news at the New York Times. Ann Arbor, MI: University of Michigan Press.

Ytre-Arne, B. (2011). 'I want to hold it in my hands': Readers' experiences of the phenomenological differences between women's magazines online and in print. Media, Culture \& Society, 33, 467-477.

Zelizer, B. (2018). Epilogue: Timing the study of news temporality. Journalism, 19, 111-121. 


\section{Tables}

Table 1

Characteristics of the Publications Examined in the Study

\begin{tabular}{|c|c|c|c|c|c|c|c|c|}
\hline Magazine & Motto & Country & Creation & Periodicity & Price & Print run & Subscribers & Core staff \\
\hline Howler & $\begin{array}{l}\text { A Magazine about } \\
\text { soccer }\end{array}$ & US & 2012 & Quarterly & $\begin{array}{l}\$ 15 \\
{[14 €]}\end{array}$ & 7,000 & 3,000 & 2 \\
\hline Panenka & El fútbol que se lee & Spain & 2011 & Monthly & $5.50 €$ & 10,000 & 4,000 & 5 \\
\hline Líbero & $\begin{array}{l}\text { Fútbol } \bullet \text { Nostalgia } \bullet \\
\text { Estilo } \bullet \text { Cultura } \bullet \\
\text { Relatos }\end{array}$ & Spain & 2012 & Quarterly & $5 €$ & 10,000 & 1,000 & 4 \\
\hline Mundial & $\begin{array}{l}\text { Reminding you why } \\
\text { you love football }\end{array}$ & UK & 2014 & Quarterly & $\begin{array}{l}£ 7 \\
{[8 €]}\end{array}$ & 15,000 & 2,500 & 7 \\
\hline So Foot & $\begin{array}{l}\text { Que le foot, et puis } \\
\text { tout le reste }\end{array}$ & France & 2003 & Monthly & $4.50 €$ & 40,000 & 24,000 & $45^{*}$ \\
\hline $\begin{array}{l}11 \\
\text { Freunde }\end{array}$ & $\begin{array}{l}\text { Das Magazin für } \\
\text { Fußballkultur }\end{array}$ & Germany & 2000 & Monthly & $5 €$ & 90,000 & 40,000 & 25 \\
\hline Offside & $\begin{array}{l}\text { Sveriges största } \\
\text { fotbollsmagasin }\end{array}$ & Sweden & 2000 & Bimonthly & $8.90 €$ & 20,000 & 15,000 & 2 \\
\hline Ballesterer & $\begin{array}{l}\text { Das Magazin zur } \\
\text { offensiven } \\
\text { Erweiterung des } \\
\text { Fufzballhorizonts }\end{array}$ & Austria & 2000 & $\begin{array}{l}10 \text { issues } \\
\text { per year }\end{array}$ & $5.50 €$ & 20,000 & 5,000 & 2 \\
\hline
\end{tabular}

Source: Authors' own elaboration with data obtained from interviews. Note: Core staff refers to permanent (part- or full-time) members that each organization has. In the case of So Foot, employees work not only for this outlet but also for the other magazines of So Press (Société d'edition de presse libre et indépendante), including Society, So Film, Tampon!, and Pédale! 